\title{
HELICOBACTER PYLORI PREVALENCE IN PATIENTS WITH CELIAC DISEASE: results from a cross-sectional study
}

\author{
Juan LASA, Ignacio ZUBIAURRE, Guillermo DIMA, Daniel PERALTA and Luis SOIFER
}

\begin{abstract}
Background - Some previously published studies have suggested an inverse relationship between celiac disease and Helicobacter pylori, raising the possibility of the protective role Helicobacter pylori could have against celiac disease development. Nevertheless, this association is inconclusive. Objectives - To determine the prevalence of Helicobacter pylori infection in celiac subjects. Methods - Between January 2013 and June 2014, patients over 18 years old undergoing upper endoscopy who required both gastric and duodenal biopsies were included for analysis. Enrolled subjects were divided in two groups: those with a diagnosis of celiac disease and those without a celiac disease diagnosis. Helicobacter pylori infection prevalence was compared between groups. Among celiac patients, endoscopic markers of villous atrophy as well as histological damage severity were compared between those with and without Helicobacter pylori infection. Results - Overall, 312 patients were enrolled. Seventy two of them had a diagnosis of celiac disease. Helicobacter pylori infection prevalence among celiac disease patients was $12.5 \%$, compared to $30 \%$ in non-celiac patients [OR=0.33 (0.15-0.71)]. There was not a significant difference in terms of the severity of villous atrophy in patients with Helicobacter pylori infection compared to those without it. There was a slight increase in the prevalence of endoscopic markers in those Helicobacter pylori-negative celiac subjects. Conclusion - Helicobacter pylori infection seems to be less frequent in celiac patients; among those celiac subjects with concomitant Helicobacter pylori infection, histological damage degree and presence of endoscopic markers suggesting villous atrophy seem to be similar to those without Helicobacter pylori infection.
\end{abstract}

HEADINGS - Celiac disease. Gluten-free diet. Helicobacter pylori.

\section{INTRODUCTION}

Celiac disease (CD) is an autoimmune intestinal disorder triggered by the ingestion of gluten ${ }^{(10)}$. Its prevalence is estimated to be $0.8 \%-1 \%$ of Western populations. It can cause gastrointestinal symptoms such as diarrhea with or without malabsorption, abdominal bloating or dyspepsia, as well as several extra-intestinal symptoms due to inadequate absorption of micronutrients, such as anemia or osteoporosis $^{(1)}$

Conventionally, $\mathrm{CD}$ produces some degree of small intestinal mucosal damage, leading to an increase in the number of intra-epithelial lymphocytes (IELs) in association with crypt hyperplasia and villous atrophy ${ }^{(17)}$. These histological changes are dependant on gluten exposure, and although characteristics, they are not exclusive. Among other causes that may be associated with duodenal lymphocytosis and, as a consequence, increased IELs, is Helicobacter pylori (Hp) infection ${ }^{(12)}$.

$\mathrm{Hp}$ is a common cause of chronic gastritis and is strongly associated with peptic ulcer disease development ${ }^{(16)}$. The relationship between Hp infection and CD is not well established: on one hand, Hp induces microscopical duodenal inflammation and thus, could be related to a more severe damage when associated with $\mathrm{CD}$. On the other hand, some previously published studies have suggested an inverse relationship between these two conditions, raising the possibility of the protective role $\mathrm{Hp}$ could have against CD development ${ }^{(7)}$. Nevertheless, this association is inconclusive, since other studies failed to show this inverse relationship ${ }^{(4)}$.

We sought to determine the prevalence of $\mathrm{Hp}$ infection in CD subjects. Also, we sought a possible association between $\mathrm{Hp}$ infection, degree of histological damage and endoscopic markers of villous atrophy in CD patients.

\section{METHODS}

A retrospective study was undertaken following a cross-sectional design. Between January 2013 and June 2014, patients over 18 years old undergoing upper endoscopy who required both gastric and duodenal biopsies were reviewed. Electronic medical records of enrolled subjects were reviewed in order to evaluate the

Declared conflict of interest of all authors: none

Disclosure of funding: no funding received

Gastroenterology Section, Internal Medicine Department. CEMIC. Buenos Aires, Argentina

Correspondence: Dr. Juan Sebastian Lasa. 1958 Austria Street. Postal code: 1425. Buenos Aires, Argentina. E-mail: drjuanslasa@gmail.com 
presence of symptoms, as well as blood test results regarding specific CD antibodies.

Subjects were excluded if information regarding clinical status and serological or histological tests were not available for analysis. The study was previously approved by the institutional review board.

\section{Endoscopic and histological procedures}

All endoscopies were performed using High-Definition Pentax endoscopes (EPKi5010; Pentax Medical Company. NJ, USA). Sedation with propofol was administered intravenously in all cases by a trained anesthesiologist. Presence of gastroduodenal lesions was recorded, as well as the presence of endoscopic markers suggesting villous atrophy: absence of duodenal folds, duodenal mucosa mosaic pattern, scallopped folds.

Four to six duodenal biopsies were taken and processed according to previously published protocol ${ }^{(2)}$. CD histological damage was graded by means of the Marsh-Oberhuber classification $^{(17)}$. Also, three biopsy samples were taken from gastric antrum and corpus. Giemsa staining was used for the detection of Hp infection. Presence of chronic gastritis using Hematoxillin-Eosin staining was also performed.

\section{Outcome measurement}

Enrolled subjects were divided in two groups: those with a diagnosis of $\mathrm{CD}$ and those without a $\mathrm{CD}$ diagnosis. $\mathrm{CD}$ was definition required the presence of some degree of villous atrophy (Marsh III) and at least one positive antibody test (anti-tisue transglutaminase, anti-endomysium or deaminated anti-gliadin antibodies). If antibodies were negative in a patient with a compatible histological finding, CD would be diagnosed if there was a reversal of villous atrophy and resolution of symptoms after at least 6 months of gluten-free diet. Hp infection prevalence was compared between groups. Among CD patients, endoscopic markers of villous atrophy as well as histological damage severity were compared between those with and without Hp infection.

\section{Statistical analysis}

Data was analysed using Stata software (Stata v11.1. Statacorp, College Station, Texas. USA). Categorical variables were described as percentages. Numerical variables were described as means with their standard deviation. For the comparison of categorical variables, chi square test was used. Odds Ratio (OR) with their corresponding 95\% confidence interval $(95 \% \mathrm{CI})$ were calculated. For the comparison of numerical variables, Student t test was used. A $P$ value of less than 0.05 was considered as statistically significant.

\section{RESULTS}

During the study period, 1500 upper endoscopies were performed. Among these, 325 subjects fulfilled inclusion criteria. Thirteen patients refused to sign the informed consent, leaving 312 patients for final analysis.

Overall, 72 patients proved to have CD, based on the above-mentioned criteria. Table 1 shows the general characteristics of CD and Non-CD groups. There were no significant differences in age and gender between groups. Three patients had negative IgA anti-transglutaminase antibodies: two of them had a positive IgA anti-endomysium and only one resulted a seronegative $\mathrm{CD}$ with a significant improvement after one year of gluten-free diet.

Most Non-CD subjects had duodenal biopsies taken even if serological tests were negative or inconclusive, in order to assess potential malabsorption as a cause for their symptoms.

Hp infection prevalence in CD patients was $12.5 \%$, compared to $30 \%$ in non-CD patients $[\mathrm{OR}=0.33(0.15-0.71)$, $P=0.003]$. There were not significant differences in terms of age and gender when comparing those $\mathrm{Hp}$-positive and Hp-negative among the CD group.

Table 2 shows the comparison of Marsh-Oberhuber classification and the prevalence of endoscopic markers of villous atrophy between groups. As it can be seen, there was not a significant difference in terms of the severity of villous

TABLE 1. Comparison of general characteristics between celiac and non-celiac subjects

\begin{tabular}{lcccc}
\hline & $\begin{array}{c}\text { Celiac disease patients } \\
(\mathbf{n}=72)\end{array}$ & $\begin{array}{c}\text { Non-celiac disease } \\
\text { patients }(\mathbf{n}=240)\end{array}$ & OR (CI95\%) & P \\
\hline Age & $45 \pm 10$ & $44 \pm 12$ & N/A & 0.92 \\
Sex $(\%$ F) & 79.17 & 70 & $1.62(0.86-3.06)$ & 0.13 \\
Positive IgA Anti-tTG (\%) & 95.83 & 4.58 & $478.81(130-1765)$ & $<0.0001$ \\
Reason for referral & & & & \\
$\quad$ Diarrhea & 41.66 & 30 & $1.66(0.96-2.87)$ & 0.08 \\
Anemia & 16.66 & 30 & $0.46(0.23-0.91)$ & 0.03 \\
Dyspepsia & 33.33 & 25 & $1.5(0.84-2.65)$ & 0.17 \\
Other & 8.35 & 15 & $0.51(0.21-1.27)$ & 0.17 \\
\hline
\end{tabular}

Anti-tTG: Anti-tisular transglutaminase antibodies

TABLE 2. Comparison of histological and endoscopic markers between Helicobacter pylori-positive and Helicobacter pylori-negative patients

\begin{tabular}{|c|c|c|c|c|}
\hline & Hp positive patients $(n=9)$ & Hp negative patients $(n=63)$ & OR (CI95\%) & $P$ \\
\hline Marsh IIIc & 66.66 & 71.42 & $0.81(0.18-3.55)$ & 1 \\
\hline Marsh IIIb/IIIa & 33.33 & 28.57 & $1.25(0.28-5.54)$ & 1 \\
\hline Endoscopic Markers of VA (\%) & 66.66 & 90.47 & $0.21(0.04-1.07)$ & 0.07 \\
\hline
\end{tabular}

VA: villous atrophy; Hp: Helicobacter pylori 
atrophy in patients with $\mathrm{Hp}$ infection compared to those without Hp. Although not significant, there was a slight increase in the prevalence of endoscopic markers in those $\mathrm{Hp}$ negative $\mathrm{CD}$ subjects.

\section{DISCUSSION}

According to our results, $\mathrm{Hp}$ infection is less common in $\mathrm{CD}$ subjects than in non-CD patients. The prevalence of $\mathrm{Hp}$ in CD patients has been previously assessed with conflicting results. The relationship between $\mathrm{Hp}$ infection and $\mathrm{CD}$ has been previously assessed with conflicting results ${ }^{(4,7,15,18)}$. Some studies such as the one published by Diamanti et al. ${ }^{(9)}$ failed to show any difference between $\mathrm{Hp}$ seroprevalence in $\mathrm{CD}$ patients versus controls. In contrast, the study reported by Konturek et al. ${ }^{(13)}$ suggested an increased $\mathrm{Hp}$ seroprevalence in CD subjects; what is more, they found a lower prevalence of CagA-positive $\mathrm{Hp}$ strains in infected subjects with $\mathrm{CD}$ than in infected controls, thus suggesting a potential relationship between $\mathrm{CD}$ and $\mathrm{Hp}$ virulence.

On the other hand, a recent cross-sectional study published by Lebwhol et al. ${ }^{(14)}$ found an inverse relationship between these two entities, even after adjusting for gender, age and socioeconomic factors. Although it is not possible to evaluate temporal association between Hp infection and CD, the authors suggested that, since there has been an increasing prevalence of $\mathrm{CD}$ and a coincidental decrease in Hp infection prevalence, $\mathrm{Hp}$ could exert a protective factor against $\mathrm{CD}$.

In addition, it is unclear the role Hp may have in CD development when considering populations with a high $\mathrm{Hp}$ prevalence, such as many Latin American countries ${ }^{(8)}$, where Hp prevalence does not seem to diminish over time. In Argentina, previously published studies have shown that $\mathrm{Hp}$ prevalence in adult population is around $49 \%$, and CD prevalence in the Buenos Aires area may be similar to the prevalence reported in some European countries ${ }^{(1)}$, thus we expected similar results than those published from these countries.

Another relevant finding of our study is that $\mathrm{Hp}$ infection does not seem to have an influential role on histological severity of $\mathrm{CD}$. Typically, $\mathrm{Hp}$ infection may produce variable degrees of duodenitis and thus may induce the presence of IELs. What is more, Hp should be ruled out as a differential diagnosis in cases of increased IELs without villous atrophy. According to this, $\mathrm{Hp}$ may contribute to increase histological damage on CD patients. On the other hand, Villanaci et al. ${ }^{(19)}$ described that among patients with $\mathrm{CD}, \mathrm{Hp}$ is associated with less severe degrees of villous atrophy. $\mathrm{Hp}$ is associated with decreased risk of other immunological-based diseases, such as asthma or other inflammatory conditions ${ }^{(5)}$. In this context, CD may not be the exception.

Experimental murine infections provide strong evidence for the hypothesis that the T-regulatory lymphocytes recruited by $\mathrm{Hp}$ have systemic effects and specifically protect against allergen-induced asthma ${ }^{(3)}$. T-regulatory lymphocytes also may play a role in the pathogenesis of $\mathrm{CD}$, since the down-regulation of cellular responses mediated by T-regulatory lymphocytes in the bowel wall is diminished in CD subjects ${ }^{(6)}$. As a consequence, patients with $\mathrm{Hp}$ and without the recruited gastric T-regulatory cells may be less likely to down-regulate immune responses to gluten. Additionally, Hp may affect ingested gluten through its modification by gastric $\mathrm{pH}$ or through its proteases, thus reducing its immunogenicity.

There are some limitations worth mentioning. Firstly, our study has the limitations a retrospective study usually carry. What is more, a cross-sectional design could not let us analyze the potential protective role suggested by previous studies. We included a relatively small number of patients. We did not evaluate socioeconomic status of enrolled patients, which may be a relevant factor related to the occurrence of both $\mathrm{Hp}$ and $\mathrm{CD}$. However, most studies regarding this issue do not evaluate the impact Hp may have - if any - in histological severity and presence of endoscopic markers of villous atrophy.

In conclusion, $\mathrm{Hp}$ infection seems to be less frequent among CD patients; among those CD subjects with concomitant $\mathrm{Hp}$ infection, histological damage degree and presence of endoscopic markers suggesting villous atrophy seem to be similar to those without Hp infection. Further well-designed, prospective cohort studies should be undertaken in order to evaluate if chronic $\mathrm{Hp}$ infection may exert a preventive role in the development of $\mathrm{CD}$.

\section{Authors' contributions}

Lasa J: study design; statistical analysis; manuscript writing. Ignacio Zubiaurre: manuscript writing; data recollection. Guillermo Dima: study design; data recollection. Daniel Peralta: data recollection. Luis Soifer: critical review and corrections of manuscript. 
Lasa J, Zubiaurre I, Dima G, Peralta D, Soifer L. Prevalência do Helicobacter pylori em pacientes com doença celíaca: resultados de um estudo transversal. Arq Gastroenterol. 2015,52(2):139-42.

RESUMO - Contexto - Alguns estudos publicados anteriormente sugerem uma relação inversa entre a doença celíaca e Helicobacter pylori, levantando a possibilidade do papel protetor que o Helicobacter pylori poderia ter contra o desenvolvimento de doença celíaca. No entanto, esta associação é inconclusiva. Objetivos - Determinar a prevalência da infecção por Helicobacter pylori em indivíduos celíacos. Métodos - Entre janeiro de 2013 e de 2014 junho, foram incluídos para análise pacientes com mais de 18 anos de idade submetidos a endoscopia para necessárias biópsias gástricas e duodenais. Os pacientes foram divididos em dois grupos: aqueles com diagnóstico de doença celíaca e aqueles sem um diagnóstico de doença celíaca. A prevalência da infecção por Helicobacter pylori foi comparada entre os grupos. Entre os pacientes celíacos, os marcadores endoscópicos de atrofia das vilosidades, bem como a gravidade do dano histológico foram comparados entre aqueles com e sem infecção pelo Helicobacter pylori. Resultados - De um total de 312 pacientes, 72 deles tiveram diagnóstico da doença celíaca. A prevalência de infecção pelo Helicobacter pylori entre pacientes com doença celíaca foi de $12,5 \%$, em comparação com $30 \%$ em pacientes não-celíacos [OR=0,33 $(0,15-0,71)]$. Não houve diferença significativa em termos da gravidade da atrofia das vilosidades em pacientes com infecção pelo Helicobacter pylori em comparação com aqueles sem ele. Houve um ligeiro aumento na prevalência de marcadores endoscópicos nos indivíduos celíacos com Helicobacter pylori-negativo. Conclusão - A infecção pelo Helicobacter pylori parece ser menos frequente em pacientes celíacos; entre esses indivíduos celíacos com concomitante infecção por Helicobacter pylori, o grau de dano histológico e a presença de marcadores endoscópicos sugerindo atrofia vilosa, parecem ser semelhantes com os sem infecção.

DESCRITORES - Doença celíaca. Dieta livre de gluten. Helicobacter pylori.

\section{REFERENCES}

1. Abu Daya H, Lebwohl B, Lewis SK, Green PH. Celiac disease patients presenting with anemia have more severe disease than those presenting with diarrhea. Clin Gastroenterol Hepatol. 2013;11(11):1472-7.

2. AGA Institute. AGA Institute Medical Position Statement on the Diagnosis and Management of Celiac Disease. Gastroenterology. 2006;131(6):1977-80.

3. Arnold IC, Dehzad N, Reuter S, Martin H, Becher B, Taube C, Müller A. Helicobacter pylori infection prevents allergic asthma in mouse models through the induction of regulatory T cells. J Clin Invest. 2011;121(8):3088-93.

4. Aydogdu S, Cakir M, Yuksekkaya HA, Tumgor G, Baran M, Arikan C, Yagci RV. Helicobacter pylori infection in children with celiac disease. Scand J Gastroenterol. 2008;43(9):1088-93.

5. Chen Y, Blaser MJ. Inverse associations of Helicobacter pylori with asthma and allergy. Arch Intern Med. 2007;167(8):821-7.

6. Chen Y, Segers S, Blaser MJ. Association between Helicobacter pylori and mortality in the NHANES III study. Gut. 2013;62(9):1262-9.

7. Ciacci C, Squillante A, Rendina D, Limauro S, Bencivenga C, Labanca F, et al. Helicobacter pylori infection and peptic disease in coeliac disease. Eur J Gastroenterol Hepatol. 2000;12(12):1283-7.

8. Corti RE. [Helicobacter pylori: some epydemiological questions in Latin America after twenty-five years]. Acta Gastroenterol Latinoam. 2009;39(3):175-6.

9. Diamanti A, Maino C, Niveloni S, Pedreira S, Vazquez H, Smecuol E, et al. Characterization of gastric mucosal lesions in patients with celiac disease: a prospective controlled study. Am J Gastroenterol. 1999;94(5):1313-9.

10. Fasano A, Catassi C. Clinical practice. Celiac disease. N Engl J Med. 2012;367(25):2419-26.
11. Gomez JC, Selvaggio GS, Viola M, Pizarro B, la Motta G, de Barrio S, et al. Prevalence of celiac disease in Argentina: screening of an adult population in the La Plata area. Am J Gastroenterol. 2001;96(9):2700-4.

12. Hammer ST, Greenson JK. The clinical significance of duodenal lymphocytosis with normal villus architecture. Arch Pathol Lab Med. 2013;137(9):1216-9.

13. Konturek PC, Karczewska E, Dieterich W, Hahn EG, Schuppan D. Increased prevalence of Helicobacter pylori infection in patients with celiac disease. Am J Gastroenterol. 2000;95(12):3682-3

14. Lebwohl B, Blaser MJ, Ludvigsson JF, Green PH, Rundle A, Sonnenberg A, Genta RM. Decreased risk of celiac disease in patients with Helicobacter pylori colonization. Am J Epidemiol. 2013;178(12):1721-30.

15. Luzza F, Mancuso M, Imeneo M, Mesuraca L, Contaldo A, Giancotti L, et al. Helicobacter pylori infection in children with celiac disease: prevalence and clinicopathologic features. J Pediatr Gastroenterol Nutr. 1999;28(2):143-6.

16. McColl KE. Clinical practice. Helicobacter pylori infection. N Engl J Med. 2010;362(17):1597-604.

17. Oberhuber G, Granditsch G, Vogelsang H. The histopathology of coeliac disease: time for a standardized report scheme for pathologists. Eur J Gastroenterol Hepatol. 1999;11(10):1185-94.

18. Rostami-Nejad M, Villanacci V, Mashayakhi R, Molaei M, Bassotti G, Zojaji H, et al. Celiac disease and Hp infection association in Iran. Rev Esp Enferm Dig. 2009;101(12):850-4.

19. Villanacci V, Bassotti G, Liserre B, Lanzini A, Lanzarotto F, Genta RM. Helicobacter pylori infection in patients with celiac disease. Am J Gastroenterol. 2006;101(8):1880-5. 